\title{
HUBUNGAN RIWAYAT PEMBERIAN ASI EKSKLUSIF DENGAN STATUS GIZI BALITA USIA 7-24 BULAN DI UPT PUSKESMAS SUSUT I KABUPATEN BANGLI
}

\section{HISTORICAL TIES OF EXCLUSIVE BREASTFEEDING WITH NUTRITIONAL STATUS OF TODDLER AGED 7-24 MONTHS IN UPT PUSKESMAS SUSUT I OF BANGLI DISTRICT}

\author{
Anak Agung Ayu Sudilestari ${ }^{1}$, I Gusti Ayu Putu Satya Laksmi², Ika Setya \\ Purwanti $^{3}$ \\ ${ }^{1}{ }_{2}{ }^{3}$ Sekolah Tinggi Ilmu Kesehatan Wira Medika Bali
}

\begin{abstract}
ABSTRAK
Pendahuluan: Kekurangan gizi merupakan masalah kesehatan utama di negara yang sedang berkembang, dan melatarbelakangi lebih dari 50\% kematian balita. Pemberian ASI paling sedikit 6 bulan direkomendasikan untuk menurunkan kesakitan dan kematian anak akibat gangguan gizi. Metode: Desain penelitian ini menggunakan metode penelitian non eksperimental dengan desain penelitian cross sectional. jumlah sampel pada menelitian ini sebanyak 83 responden dengan Teknik purposive sampling. Hasil: uji analitik menggunakan uji korelasi Rank Spearman didapatkan nilai signifikan $p=0,002(p<0,05)$ dan $r=-0,333$, sehingga dapat disimpulkan ada hubungan antara riwayat pemberian ASI eksklusif dengan status gizi balita usia 7-24 bulan. Diskusi: Pemberian ASI secara eksklusif sampai bayi berumur 6 bulan sangat penting untuk menunjang status gizi balita sehingga pertumbuhan dan perkembangannya menjadi optimal.
\end{abstract}

Kata Kunci: ASI eksklusif, gizi, balita

\section{ABSTARCT}

Introduction: Malnutrition is a major health problem in developing countries, and underlies more than 50\% of under-five mortality. Breast feeding of at least 6 months is recommended to reduce morbidity and mortality of children due to nutritional disorders. Method: This research design using non experimental research method with cross sectional research design. the number of samples in this research as many as 83 respondents with purposive sampling technique. Result: analytic test using Rank Spearman correlation test got significant value $p=0,002(p<0,05)$ and $r=-0,333$, so it can be concluded there is correlation between history of exclusive breastfeeding with nutritional status of children aged 7-24 months. Discussion: Breastfeeding exclusively until 6 months old baby is very important to support the nutritional status of toddlers so that growth and development become optimal.

Keywords: Exclusive breastfeeding, nutrition, toddlers

\begin{tabular}{ll}
\hline Alamat Korespondensi & $\begin{array}{l}\text { : Br. Puri Bukit, Kelurahan Cempaga, Kecamatan Bangli, } \\
\text { Kabupaten Bangli, 80612 } \\
\text { : gungsudilestari@yahoo.co.id }\end{array}$ \\
\hline
\end{tabular}




\section{PENDAHULUAN}

Gizi merupakan zat yang terkandung dalam makanan yang diperlukan untuk pertumbuhan perkembangan, peningkatan status kesehatan dan mencegah terjadinya masalah kesehatan. Angka gizi buruk yang tinggi masih menjadi focus perhatian dunia. Food and Agriculture Organization (FAO) menyatakan 1 dari 8 penduduk dunia menderita gizi buruk, yang sebagian besar tinggal di negara berkembang (Dirjen Gizi, 2015).

Balita kekurangan gizi di Indonesia tahun 2013 sebanyak 19,6\% dan tahun 2014 sebanyak 18,7\%, masih tinggi dari sasaran MDGs sebesar 15,5\% (Kemenkes RI, 2015). Data PSG tahun 2016 dan 2017 menyatakan Provinsi Bali mempunyai masalah gizi dengan kategori akut (pendek $<20 \%$ dan kurus $\geq 5 \%$ ). Data masalah gizi di Provinsi Bali tahun 2016 menunjukkan bahwa dari 9 Kabupaten/Kota yang ada di Provinsi Bali, Kabupaten Bangli merupakan salah satu Kabupaten yang mempunyai masalah gizi kategori akut-kronis. Data Dinas Kesehatan Kabupaten Bangli tahun 2017 didapatkan dari 12 Puskesmas yang ada, UPT Puskesmas Susut I memiliki masalah status gizi paling tinggi dengan kejadian gizi buruk sebesar 1,3 $\%$ dan gizi kurang 4\%. Studi pendahuluan yang dilakukan di UPT Puskesmas Susut I didapatkan data bahwa desa yang mempunyai permasalahan gizi paling banyak adalah Desa Susut dengan prevalensi gizi buruk sebanyak 0,3\% dan gizi kurang sebanyak $1,63 \%$.

Kekurangan gizi (malnutrisi) merupakan masalah kesehatan utama di negara yang sedang berkembang, dan melatarbelakangi lebih dari 50\% kematian balita (Depkes RI, 2014). Penanganan masalah gizi tidak hanya dapat dilakukan dengan pendekatan medis dan pelayanan kesehatan saja, melainkan penanggulangannya harus melibatkan berbagai sektor terkait, salah satunya ibu balita itu sendiri (Supariasa, 2012). Dalam rangka menurunkan angka kesakitan dan kematian anak akibat gangguan gizi, United Nation Children's Emergency Fund (UNICEF) dan World Health Organization (WHO) merekomendasikan sebaiknya anak hanya disusui air susu ibu (ASI) selama paling sedikit 6 bulan (Depkes RI, 2014).

ASI merupakan sumber gizi yang sangat ideal dengan komposisi yang seimbang dan sesuai dengan kebutuhan pertumbuhan bayi. Menyusui sejak dini mempunyai peran penting untuk menunjang pertumbuhan, kesehatan dan kelangsungan hidup bayi karena ASI kaya dengan zat gizi dan antibodi (Roesli, 2008).

Permasalahan status gizi pada balita dapat dicegah salah satunya dengan memberikan ASI secara eksklusif selama 6 bulan, berdasarkan hal tersebut penelitian ini bertujuan untuk mengetahui apakah ada hubungan Riwayat Pemberian ASI Eksklusif dengan Status Gizi Balita usia 7-24 bulan di Puskesmas Susut I Kabupaten Bangli.

\section{BAHAN DAN METODE}

Penelitian ini merupakan jenis penelitian non eksperimental dengan menggunakan desain penelitian cross sectional. Pengukuran/observasi dari variabel independen dan variabel dependen dalam penelitian ini dilakukan hanya satu kali 
pada satu waktu. Jenis Teknik sampling yang digunakan adalah purposive sampling, dengan jumlah sampel sebanyak 83 responden dan dipilih sesuai dengan kriteria inklusi dan eksklusi. Penelitian ini dilaksanakan pada tanggal 14 Mei sampai dengan 2 Juni 2018 di UPT Puskesmas Susut I Kabupaten Bangli. Variabel dalam penelitian ini adalah riwayat pemberian ASI eksklusif dan status gizi balita. Riwayat pemberian ASI eksklusif diukur menggunakan kuesioner yang diadopsi dari penelitian sebelumnya (Ekawati, 2012). Status gizi balita diukur menggunakan pengukuran antopometri berdasarkan panjang badan/usia $(\mathrm{PB} / \mathrm{U})$ yang dicocokkan dengan tabel z-score dari WHO. Analisa data dalam penelitian ini menggunakan Rank Spearman dengan nilai $\alpha=0.05$ untuk mengetahui hubungan antara riwayat pemberian ASI eksklusif dengan status gizi balita usia 7-24 bulan di UPT Puskesmas Susut I Kabupaten Bangli.

\section{HASIL}

\section{Karakteristik Responden}

Tabel 1. Distribusi responden berdasarkan umur.

\begin{tabular}{lcc}
\hline $\begin{array}{c}\text { Rentang } \\
\text { usia }\end{array}$ & Frekuensi (n) & Persentase (\%) \\
\hline $17-25$ & 19 & 22.9 \\
\hline $26-35$ & 56 & 67.5 \\
\hline $36-45$ & 8 & 9.6 \\
\hline Total & 83 & 100 \\
\hline
\end{tabular}

Tabel 1. menunjukkan sebagian besar responden berada pada rentang usia dewasa awal (26-35 tahun) yaitu sebanyak 56 orang $(67,5 \%)$.

Tabel 2. Distribusi responden berdasarkan jenis kelamin

\begin{tabular}{lcc}
\hline Jenis Kelamin & Frekuensi (n) & Persentase $(\%)$ \\
\hline Laki-laki & 38 & 45.8 \\
\hline Perempuan & 45 & 54.2 \\
\hline Total & 83 & 100 \\
\hline
\end{tabular}

Tabel 2 menunjukkan sebagian besar $(54,2 \%)$ balita berjenis kelamin perempuan sebanyak 45 orang.

Tabel 3. Distribusi responden berdasarkan pendidikan

\begin{tabular}{lcc}
\hline Pendidikan & $\begin{array}{c}\text { Frekuensi } \\
(\mathrm{n})\end{array}$ & $\begin{array}{c}\text { Persentase } \\
(\%)\end{array}$ \\
\hline SD & 2 & 2.4 \\
\hline SMP & 20 & 24.1 \\
\hline SMU/sederajat & 48 & 57.8 \\
\hline
\end{tabular}




\begin{tabular}{lcc}
\hline $\begin{array}{l}\text { Akademi/Perguruan } \\
\text { Tinggi }\end{array}$ & 13 & 15.7 \\
\hline Total & 83 & 100 \\
\hline
\end{tabular}

Tabel 3 menunjukkan karakteristik responden berdasarkan Pendidikan sebagian besar berpendidikan SMU/sederajat yaitu 48 orang $(57,8 \%)$.

Tabel 4. Distribusi responden berdasarkan ibu bekerja

\begin{tabular}{lcc}
\hline \multicolumn{1}{c}{ Ibu Bekerja } & Frekuensi (n) & $\begin{array}{c}\text { Persentase } \\
(\%)\end{array}$ \\
\hline Bekerja & 23 & 27.7 \\
\hline Tidak Bekerja & 60 & 72.3 \\
\hline Total & 83 & 100 \\
\hline
\end{tabular}

Tabel 4 menunjukkan sebagian besar ibu-ibu tidak bekerja, yaitu sebanyak 60 orang $(72,3 \%)$.

Tabel 5. Distribusi responden berdasarkan dukungan keluarga

\begin{tabular}{lcc}
\hline Dukungan keluarga & Frekuensi (n) & Persentase (\%) \\
\hline Didukung & 74 & 89.2 \\
\hline Tidak didukung & 9 & 10.8 \\
\hline Total & 83 & 100 \\
\hline
\end{tabular}

Tabel 5 menunjukkan bahwa sebagian besar ibu-ibu mendapatkan dukungan dari keluarganya untuk memberikan ASI, yaitu sebanyak 74 orang $(89,2 \%)$.

Tabel 6. Distribusi responden berdasarkan kepercayaan

\begin{tabular}{lcc}
\hline Kepercayaan & Frekuensi $(\mathrm{n})$ & Persentase $(\%)$ \\
\hline Ada & 0 & 0 \\
\hline Tidak ada & 83 & 100 \\
\hline
\end{tabular}

Tabel 6 menunjukkan tidak ada kepercayaan tertentu yang mempengaruhi dalam pemberian ASI.

\section{Hasil Penelitian Berdasarkan Variabel Penelitian}

Tabel 7. Riwayat pemberian ASI eksklusif

$$
\text { Riwayat }
$$

Pemberian ASI Frekuensi (n) Persentase (\%)

Eksklusif

\begin{tabular}{|c|c|c|}
\hline ASI Eksklusif & 20 & 24.1 \\
\hline $\begin{array}{ll}\text { Tidak } & \text { ASI } \\
\text { Eksklusif } & \end{array}$ & 63 & 75.9 \\
\hline Total & 83 & 100 \\
\hline
\end{tabular}


Tabel 7 menunjukkan bahwa sebagian besar responden tidak memberikan ASI secara eksklusif, yaitu sebanyak 63 orang $(75,9 \%)$.

Tabel 8. Status gizi balita usia 7-24 bulan

\begin{tabular}{lcc} 
Status gizi & Frekuensi (n) & Persentase (\%) \\
\hline Pendek & 3 & 3.6 \\
\hline Normal & 73 & 88 \\
\hline Tinggi & 7 & 8.4 \\
\hline Total & 83 & 100 \\
\hline
\end{tabular}

Tabel 8 menunjukkan bahwa sebagian besar balita mempunyai status gizi normal $88 \%$ (73 orang) berdasarkan panjang badan/usia (PB/U).

\section{Hasil Analisa Data}

Tabel 9. Hubungan riwayat pemberian ASI eksklusif dengan status gizi balita usia 7-24 bulan

\begin{tabular}{|c|c|c|c|c|c|c|c|c|c|c|}
\hline \multirow{3}{*}{\begin{tabular}{|c|} 
Riway \\
at \\
Pemb \\
erian \\
ASI
\end{tabular}} & \multicolumn{8}{|c|}{ Status Gizi } & \multirow{3}{*}{$\begin{array}{c}p \\
\text { valu } \\
e\end{array}$} & \multirow{3}{*}{$r$} \\
\hline & \multicolumn{2}{|c|}{ Pendek } & \multicolumn{2}{|c|}{ Normal } & \multicolumn{2}{|c|}{ Tinggi } & \multicolumn{2}{|c|}{ Total } & & \\
\hline & $\mathbf{n}$ & $\%$ & $n$ & $\%$ & $n$ & $\%$ & $\mathrm{n}$ & $\%$ & & \\
\hline \begin{tabular}{|l|} 
ASI \\
Eksklu
\end{tabular} & 0 & 0.00 & 15 & 18.07 & 5 & 6.02 & 20 & 24.10 & & \\
\hline $\begin{array}{l}\text { Tidak } \\
\text { ASI } \\
\text { Eksklu } \\
\text { sif }\end{array}$ & 3 & 3.61 & 58 & 69.88 & 2 & 2.41 & 63 & 75.90 & 0.002 & $-0,333$ \\
\hline Jumlah & 3 & 3.61 & 73 & 87.95 & 7 & 8.43 & 83 & 100 & & \\
\hline
\end{tabular}

Tabel 9 menunjukkan bahwa sebagian besar (69,88\%) responden mempunyai riwayat tidak diberikan ASI Eksklusif dan mempunyai status gizi normal. Dari uji korelasi dengan menggunakan uji Spearman's rho didapatkan nilai signifikansi $(p)=0,002$ dengan derajat kemaknaan $\alpha \leq 0,05$ maka H1 diterima, artinya ada hubungan riwayat pemberian ASI Eksklusif dengan status gizi balita usia 7-24 bulan di UPT Puskesmas Susut I Kabupaten Bangli. Dari output SPSS diperoleh koefisien korelasi sebesar 0,333 yang berarti tingkat kekuatan hubungan antara variabel riwayat pemberian ASI Eksklusif dengan status gizi sebesar -0.333 atau korelasi cukup. 


\section{PEMBAHASAN}

\section{Riwayat Pemberian ASI Eksklusif}

Hasil penelitian yang dilakukan di Puskesmas Susut I Kabupaten Bangli didapatkan bahwa sebagian besar (75.9\%) balita usia 7-24 bulan tidak diberikan ASI Eksklusif. Jawaban responden terhadap kuesioner yang diberikan didapatkan sebagian besar ibu beranggapan bahwa diberikan ASI saja sampai bayi berumur 6 bulan tidak cukup untuk memenuhi kebutuhan bayi. Ditandai dengan bayi masih menangis setelah diberikan ASI. Sehingga ibu memberikan makanan tambahan kepada bayi seperti susu formula, pisang, biskuit serta bubur bayi kepada bayinya sebelum bayi berusia 6 bulan. Alasan lain dari responden yang tidak memberikan ASI secara eksklusif dikarenakan air susu yang tidak keluar pada hari-hari pertama sehingga bayi perlu diberikan makanan tambahan sebelum umur 6 bulan. Selain itu juga, dikarenakan produksi ASI kurang sehingga perlu ditambah dengan susu formula atau minuman lainnya.

Pernyataan tersebut sesuai dengan yang dikemukakan oleh Roesli, 2008 yang menyatakan rasa cemas merupakan alasan utama para ibu untuk tidak memberikan ASI secara eksklusif. Walau banyak ibu yang merasa kurang produksi ASInya, tapi yang secara bioligis memang kurang produksinya hanya sedikit (25\%), selebihnya (95-98\%) dapat menghasilkan ASI yang cukup untuk bayinya.

Menurut peneliti, rendahnya pemberian ASI secara eksklusif dikarenakan sebagian besar ibu merasa takut bayinya belum kenyang hanya dengan diberikan ASI saja. Pemahaman ibu tentang pemberian ASI masih kurang sehingga banyak ibu yang malah gagal memberikan ASI secara eksklusif pada bulan keenam, mereka hanya meberikan ASI eksklusif sampai bayi berumur lima bulan. Saat wawancara juga didapatkan bahwa responden sebagian besar baru mempunyai satu anak, sehingga pengalaman ibu dalam memberikan ASI eksklusif masih kurang.

\section{Status Gizi Balita Usia 7-24 Bulan}

Hasil penelitian yang dilakukan di UPT Puskesmas Susut I Kabupaten Bangli didapatkan data dari 83 responden balita yang berusia 7-24 bulan, sebagian besar (88\%) mempunyai status gizi normal.

Hal ini dapat dipengaruhi oleh pendidikan orang tua dan status pekerjaan ibu. Dari hasil penelitian didapatkan sebagian besar ibu mempunyai pendidikan SMU/sederajat. Sesuai dengan yang dinyatakan oleh Hasdiana (2014), pendidikan orang tua mempengaruhi cara orang tua dalam mengasuh anak, pendidikan ibu akan sangat berpengaruh terhadap pengetahuan ibu tentang gizi serta pola hidup bersih dan sehat.

Hasil penelitian juga didapatkan sebagian besar ibu tidak bekerja $(72,3 \%)$ mempunyai balita dengan status gizi normal, hal tersebut sejalan dengan penelitian yang dilakukan oleh Sholikah, Rustiana dan Yuniastuti (2017) tentang faktor-faktor yang berhubungan dengan status gizi balita di pedesaan dan perkotaan menyatakan, ibu yang tidak bekerja dalam keluarga dapat mempengaruhi asupan gizi balita karena ibu berperan sebagai pengasuh dan pengatur konsumsi makanan anggota keluarga. Sedangkan ibu yang bekerja tidak memiliki waktu yang cukup untuk mengasuh dan merawat anaknya sehingga anaknya dapat menderita gizi kurang. 
Menurut peneliti, status gizi yang normal tidak hanya dipengaruhi oleh pemberian ASI secara eksklusif, tapi juga dapat dipengaruhi oleh tingkat pendidikan ibu yang cukup tinggi sehingga ibu mempunyai pengetahuan yang cukup untuk memenuhi makanan yang bergizi bagi anaknya. Dan karena ibu yang tidak bekerja mempunyai waktu yang lebih banyak dalam merawat anaknya termasuk menyediakan makanan yang sehat dan bergizi.

\section{Hubungan Riwayat Pemberian ASI Eksklusif dengan Status Gizi Balita Usia 7-24 Bulan}

Penelitian yang dilakukan di UPT Puskesmas Susut I Kabupaten Bangli didapatkan hasil uji korelasi dengan menggunakan uji Spearman's rho menunjukkan nilai signifikansi lebih kecil dari 0,05 yaitu sebesar 0,002 yang berarti H1 diterima, yang menyatakan ada hubungan antara riwayat pemberian ASI eksklusif dengan status gizi pada balita usia 7-24 bulan di UPT Puskesmas Susut I Kabupaten Bangli. Ditunjukkan juga dengan nilai korelasi yang cukut kuat yaitu sebesar $-0,333$.

Penelitian ini sejalan dengan penelitian yang dilakukan oleh Kamudoni, et al (2015) tentang Exclusive breastfeeding duration during the first 6 months of life is positively associated with length-for-age among infants 6-12 months old, in Mangochi district, Malawi menyebutkan bahwa ASI esklusif dalam 6 bulan pertama kehidupan dikaitkan dengan peningkatan pertumbuhan linier, namun tidak untuk penambahan berat badan bayi pada awal kehidupan.

Hasil penelitian juga menunjukkan korelasi sebesar -0,333 yang berarti adanya hubungan negatif antara riwayat pemberian ASI eksklusif dengan status gizi balita. Hasil penelitian ini berbeda dengan penelitian yang dilakukan oleh Kumar, A dan Singh, V.K, 2015 yang berjudul A Study of Exclusive Breastfeeding and its Impact on Nutritional Status of Child in EAG States, yang menyebutkan bahwa tingkat keparahan stunting, gizi kurus dan berat badan rendah cenderung menurun karena diberikan ASI eksklusif.

Menurut peneliti, adanya korelasi yang negatif disebabkan karena adanya faktor-faktor selain ASI eksklusif yang mepengaruhi status gizi balita seperti pemberian susu formula, sosial ekonomi keluarga yang mendukung, pendidikan dan pengetahuan orang tua dan pola pengasuhan yang baik. Keluarga dengan status ekonomi baik akan berpengaruh dalam memenuhi kebutuhan makanan balita sahingga gizi balita dapat terpenuhi. Status ekonomi seperti penghasilan akan mempengaruhi daya beli orangtua sehingga orang tua mampu menyediakan makanan yang berkualitas dan bergizi. Pola pengasuhan orang tua yang baik disamping memberikan makanan yang bergizi, orang tua juga akan memberikan perawatan yang terbaik untuk anaknya sehingga status gizi anak akan baik juga.

Dari hasil jawaban kuesioner didapatkan bahwa sebagian besar ibu tidak bekerja, sehingga ibu secara maksimal dapat merawat anaknya dan mengatur konsumsi anaknya. Wawancara yang dilakukan dengan responden mengatakan ibuibu yang tidak bisa memberikan ASI nya berusaha memberikan makanan yang bergizi kepada anaknya sehingga anaknya bisa mempunyai gizi yang baik dan tidak gampang sakit. Menurut peneliti, untuk mencapai status gizi yang baik harus didukung oleh pemberian nutrisi yang baik. ASI adalah makanan yang terbaik bagi bayi sampai berusia 6 bulan, yang selanjutnya akan ditambahkan dengan makanan 
pendamping dan ASI tetap diberikan sampai anak berusia 2 tahun. Dengan diberikannya ASI secara eksklusif akan menunjang optimalnya pertumbuhan dan perkembangan anak.

\section{SIMPULAN DAN SARAN}

\section{Simpulan}

Berdasarkan hasil uraian pembahasan penelitian maka dapat disimpulkan riwayat pemberian ASI eksklusif pada balita usia 7-24 bulan di UPT Puskesmas Susut I Kabupaten Bangli adalah sebagian besar, 63 orang $(75,9 \%)$ tidak diberikan ASI eksklusif.

Status gizi balita usia 7-24 bulan di UPT Puskesmas Susut I Kabupaten Bangli adalah sebagian besar mempunyai status gizi normal yaitu sebanyak 73 orang $(88 \%)$.

Dan analisa data menggunakan uji Spearman's rho didapatkan $\mathrm{p}$ value $0,002<0,05$ da $r$ sebesar -0.333 yang berarti ada hubungan negatif antara riwayat pemberian ASI eksklusif dengan status gizi pada balita usia 7-24 bulan.

\section{Saran}

Bagi puskesmas diharapkan penelitian ini dapat digunakan sebagai salah satu acuan dalam meningkatkan pencapaian pemberian ASI eksklusif kepada bayi sehingga dapat menunjang status gizi balita menjadi optimal, seperti memberikan penyuluhan tersendiri tentang ASI eksklusif kepada masyarakat.

Tenaga kesehatan perlu meningkatkan sosialisasi terhadap pentingnya pemberian ASI secara eksklusif dan manfaat pemberian ASI eksklusif bagi pertumbuhan dan perkembangan balita sehingga mampu meningkatkan stutus gizi balita.

Penelitian lebih lanjut tentang pemberian ASI eksklusif dan gtatus gizi balita dapat dilakukan dengan menambahkan faktor-faktor yang mendukung seperti pengetahuan orang tua tentang ASI eksklusif dan penghasilan orang tua.

Ibu mampu memberikan ASI kepada anaknya secara eksklusif sampai anaknya berusia enam bulan. Keluarga juga memberikan dukungan kepada ibu untuk memberikan ASI eksklusif sehingga mampu meningkatkan status gizi anak.

\section{DAFTAR PUSTAKA}

Dirjen Gizi. 2015. Kesehatan Dalam Kerangka SDGS. Jakarta: Kemenkes RI.

Ekawati, N.L.P. 2012 Hubungan Pemberian ASI Eksklusif dengan Klasifikasi Pneuminia Pada Anak Usia 6 Bulan - 2 Tahun di Ruang Anak RSUP Sanglah Denpasar (Skripsi). Denpasar: Poltekkes Denpasar Kemenkes RI

Hasdianah, Siyoto dan Peristyowati. 2014. Gizi, Pemanfaatan Gizi, Diet, dan Obesitas. Yogyakarta: Nuha Medika.

Kamudoni, et al. 2014. Exclusive breastfeeding duration during the first 6 months of life is positively associated with length-for-age among infants 6-12 months old, in Mangochi district, Malawi. European Journal of Clinical Nutrition. 
Norway. Department of Community Medicine, Faculty of Medicine, University of Oslo. 69 : p.96-101.

Kemenkes RI. 2011. Keputusan Menteri Kesehatan RI Nomor: 1995/MENKES/SK/XII/2010 tentang Standar Antropometri Penilaian Status Gizi Anak. Jakarta: Direktorat Bina Gizi.

\section{Kemenkes RI} . 2014. Riset Kesehatan Dasar (RISKESDAS). Jakarta: Balitbang 2015. Profil Kesehatan Indonesia. Jakarta: Kementrian Kesehatan Republik Indonesia. . 2015. Peraturan Pemerintah RI No. 33 Tahun 2012 tentang Pemberian ASI Eksklusif. Denpasar: Dinkes Provinsi Bali. I. 2015. Pedoman Gizi Seimbang. Jakarta. Dirjen Gizi dan KIA. dan KIA. . 2015. Petunjuk Pelaksanaan Surveilans Gizi. Jakarta. Dirjen Gizi 2017. Hasil Pemantauan Status Gizi (PSG) Tahun 2016. Jakarta. Dirjen Kesmas. 2018. Hasil Pemantauan Status Gizi (PSG) Tahun 2017. Jakarta. Dirjen Kesmas.

Roesli, U. 2008. Inisiasi Menyusu Dini Plus ASI Eksklusif. Jakarta: Pustaka Bunda. Sardjoko, S. 2016. Pelaksanaan Pengentasan Kelaparan serta Konsumsi \& Produksi Berkelanjutan dalam Tujuan Pembangunan Berkelanjutan (SDGs) di Indonesia. Palembang: Kementrian PPN/Bappenas.

Setyorini, R.N.,Widjanarko, B. dan Sugihantono, A. 2017. Faktor-faktor yang Mempengaruhi Pemberian ASI Eksklusif di Wilayah Kerja Puskesmas Pegandan Kota Semarang. Jurnal Kesehatan Masyarakat. Universitas Diponegoro. 5 (3) : p.620-628.

Sholikah, Rustiana dan Yuniastuti. 2017. Faktor-faktor yang Berhubungan dengan Status Gizi Balita di Pedesaan dan Perkotaan, Public Health Perspective Journal 2 (1) (2017) 9-18, Universitas Negeri Semarang, http://journal.unnes.ac.id/sju/index.php/phpj

Supariasa, I. D. W., B. Bakri dan I. Facar. 2012. Penilaian Status Gizi. Jakarta: ECG. 